Article

\title{
The High-Velocity Impact Behaviour of Kevlar Composite Laminates Filled with Cork Powder
}

\author{
Ana Martins Amaro ${ }^{1, *(\mathbb{D}}$, Paulo Nobre Balbis Reis ${ }^{2}{ }^{\mathbb{D}}$, Ines Ivañez $\left.{ }^{3}{ }^{(}\right)$, Sonia Sánchez-Saez ${ }^{3}$, \\ Shirley Kalamis Garcia-Castillo ${ }^{3}$ and Enrique Barbero ${ }^{3}$ (D) \\ 1 CEMMPRE, Department of Mechanical Engineering, University of Coimbra, 3030-788 Coimbra, Portugal \\ 2 C-MAST, Department of Electromechanical Engineering, University of Beira Interior, \\ 6201-100 Covilhã, Portugal; preis@ubi.pt \\ 3 Department of Continuum Mechanics and Structural Analysis, University Carlos III of Madrid, \\ 28911 Leganés, Spain; idel@ing.uc3m.es (I.I.); ssanchez@ing.uc3m.es (S.S.-S.); \\ sgcastil@ing.uc3m.es (S.K.G.-C.); ebarbero@ing.uc3m.es (E.B.) \\ * Correspondence: ana.amaro@dem.uc.pt; Tel.: +351-239-790-700
}

Received: 25 June 2020; Accepted: 31 August 2020; Published: 3 September 2020

check for updates

\begin{abstract}
The literature reports benefits when the cork powder obtained from industrial by-products is used as the filler of composite laminates. For example, while the fatigue life is insensitive to the presence of cork in the resin, significant improvements are achieved in terms of to low-velocity impact strength. However, in terms of ballistic domain, the literature does not yet report any study about the effect of incorporating powdered cork into resins. Therefore, this study intended to analyse the ballistic behaviour and damage tolerance of Kevlar/epoxy reinforced composites with matrix filled by cork powder. For this purpose, high-velocity impacts were studied on plates of Kevlar bi-directional woven laminates with surfaces of $100 \times 100 \mathrm{~mm}^{2}$. It was possible to conclude that the minimum velocity of perforation is $1.6 \%$ higher when the cork powder is added to the resin, but considering the dispersion, this small difference can be neglected. In terms of damage areas, they are slightly lower when cork dust is added, especially for velocities below the minimum perforation velocity. Finally, the residual bending strength shows that these composites are less sensitive to impact velocity than the samples with neat resin. In addition to these benefits, cork powder reduces the amount of resin in the composite, making it more environmentally friendly.
\end{abstract}

Keywords: Kevlar composite laminates; ballistic impact; cork powder; mechanical testing

\section{Introduction}

The industrial world is under enormous pressure to use more sustainable materials in their products, in order to alleviate problems related to air pollution, global warming and shortages of fossil fuels. According to studies published in 2015, for example, the transport sector alone is responsible for $25 \%$ of greenhouse emissions in Europe, $16 \%$ in Australia and 23\% in the USA [1], and this tendency is to increase if nothing is done to counter it.

Fibre-reinforced polymers are attractive candidates to replace the traditional materials, because they have high specific strength and stiffness, and excellent fatigue resistance and stability. However, these materials are also subjected to the same sustainable pressures, and today, it is possible to observe a significant increase in the use of natural fibres. They are renewable, biodegradable and available throughout the world. The various review articles available in the open literature denote this enormous interest [2-7], even in terms of impact strength [8-10].

Natural fibres are strong enough, light in weight, abundant, non-abrasive and cheap [11-13]. When compared to other fibres, they have a specific weight that is about half of a glass fibre's weight 
and a tensile modulus quite similar to that of aramid fibres [14]. Moreover, fibres with higher cellulose content, higher degrees of polymerisation and lower microfibrillar angles exhibit higher tensile strength and moduli [15]. On the other hand, the main disadvantages are their lower thermal stability, which limits their use with some thermoplastics, and low resistance to moisture and dimensional stability, which can lead to debonding and microcracking in the composite [16].

However, there is real evidence that forests in developed countries are dwindling and other natural products are emerging, especially those obtained from agricultural by-products or agro-waste materials. In this context, the different cork wastes resulting from the manufacture of various cork-based products are very attractive because they maintain the same intrinsic characteristics of cork, such as low specific weight, great elasticity, flexibility and durability, specific stiffness and strength, impermeability to liquid and gases, resistance to wear and fire, dimensional stability and resistance to reactive agents and microorganisms [17-20]. These cork wastes present different densities, amounts of moisture, granulometries, sizes, levels of ash content and tannin concentrations [21,22], and all of them were conveniently characterized by Gil [23]. For example, cork powder is the most important waste from cork processing, where only the cork-stopper production is responsible for $25 \%$ to $30 \%$ of the raw material. According to the Portuguese Standards NP-114 and NP-273, cork powder has dimensions lower than $0.25 \mathrm{~mm}$ and there are different types according to their origin: the grinding powder, from granulation or pre-grinding; the cleaning powder, without impurities; the finishing powder, from cut and sanding operations; the agglomerated cork panels' finishing powder; the agglomerated cork stoppers and disks' finishing powder; the insulation cork board powder $[23,24]$. These powders have been used mainly as combustion fuels (due to its high heating value) [22,23]. A small fraction are also used as filling agents (to improve the quality of cork-stoppers) [23,24]; in the production of linoleum [23,24]; in applications in agglomerates [23,24]; as briquettes [23,24]; as agricultural substrates [23,24]; and more recently, cork powders have been used as pollutant adsorbents or as absorbents in oil splits due to their good adsorption properties [24-26], and in the production of composites due to their physical and mechanical properties [27,28].

Sanchez-Saez et al. [29] developed an experimental study, where the multi-impact behaviour of agglomerated-cork specimens was analysed. They observed a great capability of agglomerated cork to absorb energy even after several consecutive impacts. The damage resistance of sandwich structures with agglomerated cork core and flax/epoxy laminates face sheets subjected to low- and high-velocity impacts was evaluated by Sarasini et al. [30]. They observed that cork cell walls experienced buckling, and in this context, the energy absorption at high strains can be quite considerable without signs of cell walls breakage. This suggest an almost complete recovery of their original shape and size. Moreover, the composite structures during its service life can be damaged due to impact loading, and this damage in composite material is of primary concern because it leads to large reduction in strength and compromises their structural integrity [30,31].

Reis et al. [32], for example, developed studies in composites incorporating cork powder, obtained from industrial by-products, and observed benefits in terms of impact strength and glass transition temperature $\left(\mathrm{T}_{\mathrm{g}}\right)$. When $2.5 \mathrm{wt} . \%$ was added to the polyester resin, the impact strength increased to around $18.5 \%$ and the $\mathrm{T}_{\mathrm{g}}$ to about $7.3 \%$ compared to the values obtained with the pristine resin. In another experimental study [33], these authors obtained benefits in terms of elastic recuperation and damaged area when cork powder was added to an epoxy resin, and higher penetration threshold and residual tensile strength of the laminates that incorporate the cork powder. For example, the elastic recuperation increased by about $26 \%$, for a $21 \mathrm{~J}$ impact energy, and the damaged area decreased by around $15 \%$ for the same impact energy and compared to the values obtained for laminates with neat resin. Regarding the penetration threshold, these values were about $15 \%$ while the residual strength decreased around $47 \%$ for laminates subjected to an impact energy of $21 \mathrm{~J}$ [33].

In terms of fatigue properties, independently of the lower static bending strength (around 10\% lower when $3 \mathrm{wt} . \%$ of cork powder was added to the resin), Reis et al. [34] observed, based on a statistical analysis of fatigue data, that fatigue life is insensitive to the presence of cork into the resin. 
Finally, due to the viscoelastic properties of cork and polymeric matrices, Reis et al. [35] performed a study where the stress relaxation and creep behaviour of multiphase composites incorporating cork powder were analysed in detail. For this purpose, composites with the same lay-up but with different fibres were produced. They concluded that higher values of relaxation and creep displacement occur when Kevlar fibres are used, but, independently of the fibres, higher values were also observed when cork powder was introduced into the resin.

Therefore, based on the benefits achieved with this industrial by-product, the main goal of this work was to study the high-velocity impact behaviour of Kevlar composite laminates filled by cork powder, in order to obtain full knowledge of all loading modes. These fibres are of particular interest for military and civilian purposes, due to their high degree of toughness and good impact/ballistic performance. In fact, aramid fibres fail by a series of small fibril failures that absorb a significant amount of energy, resulting in very high toughness. For that purpose, this work focused on the ballistic behaviour and damage tolerance of Kevlar/epoxy reinforced composites, in which the epoxy matrix is filled with cork powder. The perforation velocity and energy absorption were estimated from experimental tests and damaged area was obtained by both C-scan ultrasound technique and visual inspection from impacted specimens. In order to evaluate the damage tolerance, bending after impact (BAI) tests were carried out.

\section{Experimental Procedure}

Composite laminate plates involving Kevlar bi-directional woven fabrics (taffeta with $281 \mathrm{~g} / \mathrm{cm}^{2}$ ) and an Ampreg 22 epoxy resin with an Ampreg 22 hardener standard (both supplied by Gurit) were manufactured with a useful size of $300 \times 300 \times 3.3 \mathrm{~mm}^{3}$ by hand lay-up technique. For this purpose, nine ply laminates, all in the same direction, were used. After that, the system was placed inside a vacuum bag and a load of $2.5 \mathrm{kN}$ was applied for $48 \mathrm{~h}$ to ensure a uniform laminate thickness. During the first $10 \mathrm{~h}$ the bag remained attached to a vacuum pump to eliminate possible air bubbles in the composite laminates. Finally, the post-cure was carried out in an oven at $45^{\circ} \mathrm{C}$ for $48 \mathrm{~h}$ to guarantee a convenient curing stage.

Similar composite laminates with epoxy matrix filled by cork powder were also produced by the same methodology. The cork powder used consists of a residue obtained during the final sanding phase of cork-stoppers and it was collected at Amorim Cork S.A. (Valada, Portugal) industrial facilities. The cork powder presents a particle size, in terms of percentile, of $d(0.1)=18.6 \mu \mathrm{m}, \mathrm{d}(0.5)=78.9 \mu \mathrm{m}$ and $\mathrm{d}(0.9)=208.3 \mu \mathrm{m}$; a bulk density of $0.1095 \mathrm{~g} . \mathrm{cm}^{-3}$; and a humidity of $\approx 5.1 \%$. The low moisture content observed is explained by the fact that the raw material from which the cork powder was obtained underwent several heating and drying operations [23]. Regardless of the low moisture content observed, to improve the adhesion with the resin, the cork powder was still dried in an oven (Heraus, model UT 6060) at $120{ }^{\circ} \mathrm{C}$ for $2 \mathrm{~h}$ and stored until used in a desiccator. Finally, the cork powder ( $3 \mathrm{wt} . \%$ of the epoxy resin-hardener mixture) and epoxy resin were mixed at $900 \mathrm{rpm}$ for $2 \mathrm{~h}$, with resource to an electrical mixer, in an ultrasonic bath for an uniform distribution of the cork particles into the resin. In order to avoid the formation of air bubbles, the mixture was degassed in a vacuum oven, followed by addition of hardener agent. However, more details about the cork fraction used and respective manufacturing process can be found in [32-34].

According to Pintor et al. [24], cork's structure is formed by hollow polyhedral prismatic cells, which have a honeycomb shape when observed from the radial direction and rectangular when observed from the transversal direction [9]. The area of the prism base is 4 to $6 \times 10^{-6} \mathrm{~cm}^{2}$, with a mean prism edge of 13-15 $\mu \mathrm{m}$ and a prim height of 30-40 $\mu \mathrm{m}$. The mean cell volume is around $2 \times 10^{-8} \mathrm{~cm}^{3}$ and the number of cells per unit is 4 to $7 \times 10^{7} \mathrm{~cm}^{-3}$. The cell walls are thin, with a thickness of 1 to $1.5 \mu \mathrm{m}$, in which is concentrated the solid mass volume fraction of the cork [36]. The cork powder keeps the same cellular structure intact; however, when the size of cork particles deceases, the number of closed cells decreases and the external surface areas of the particles increase, and consequently, the number of open through-cut cells increases [36]. Based in studies reported by Pereira [36], a cork 
particle of volume $0.015 \mathrm{~mm}^{3}$ (around $0.25 \times 0.25 \times 0.25 \mathrm{~mm}^{3}$ ) contains about 500 cells $(7-9$ cell per one row) in which only a fraction of 6 to 8 cells in one row are closed. This evidence and respective particle shape and morphology are well reported by scanning electron micrographs, in a review paper compiled by Pereira [36], for cork particles similar to those used in this study.

The high-velocity impacts were carried out on plates of Kevlar bi-directional woven laminates with surface of $100 \times 100 \mathrm{~mm}^{2}$. The specimen's size was big enough that the damaged area did not reach the border of the laminate. The projectile used for impact tests was of steel with a spherical geometry of $7.5 \mathrm{~mm}$ diameter and a density of $7800 \mathrm{~kg} / \mathrm{m}^{3}$. In order to carry out the impact tests, a gas gun (Figure 1) was used to impulse the projectile at the required velocity. This gas gun consists of several clearly differentiated zones: the load and accommodation area of the projectile, the pressure chamber that impulses the projectile against the target, a launch tube and a frame where the laminate is embedded.

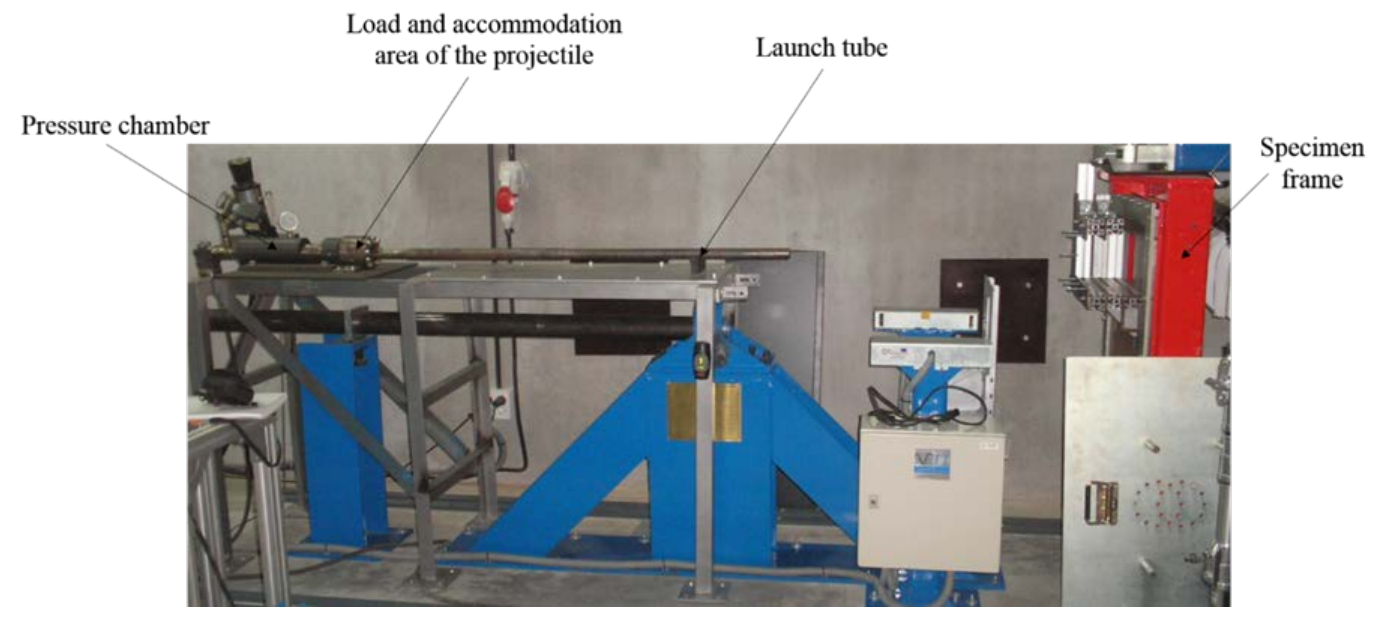

Figure 1. Photo of the equipment used in the high-velocity impact tests.

To impulse the projectile, the pressure of the gas used was regulated and two different types of gas were used: helium to achieve the highest velocities, and Stargon ${ }^{\circledR}$ a mixture of argon, carbon dioxide and oxygen manufactured by NIPPON GASES ESPAÑA, S.L.U. (Madrid, Spain) for the lowest velocities.

The impact tests were recorded with a high-velocity camera (Figure 2), which was used to pick up essential information such as the impact and residual velocities. The camera used was a Photron Fastcam ATX, which is able to reach 250,000 frames per second. In these tests the acquisition data velocity was 90,000 fps. The camera was placed parallel to the frame of essays. An ARRI ARRISON 12 PLUS lamp was used for lighting. This lamp has a power of $1200 \mathrm{~W}$.

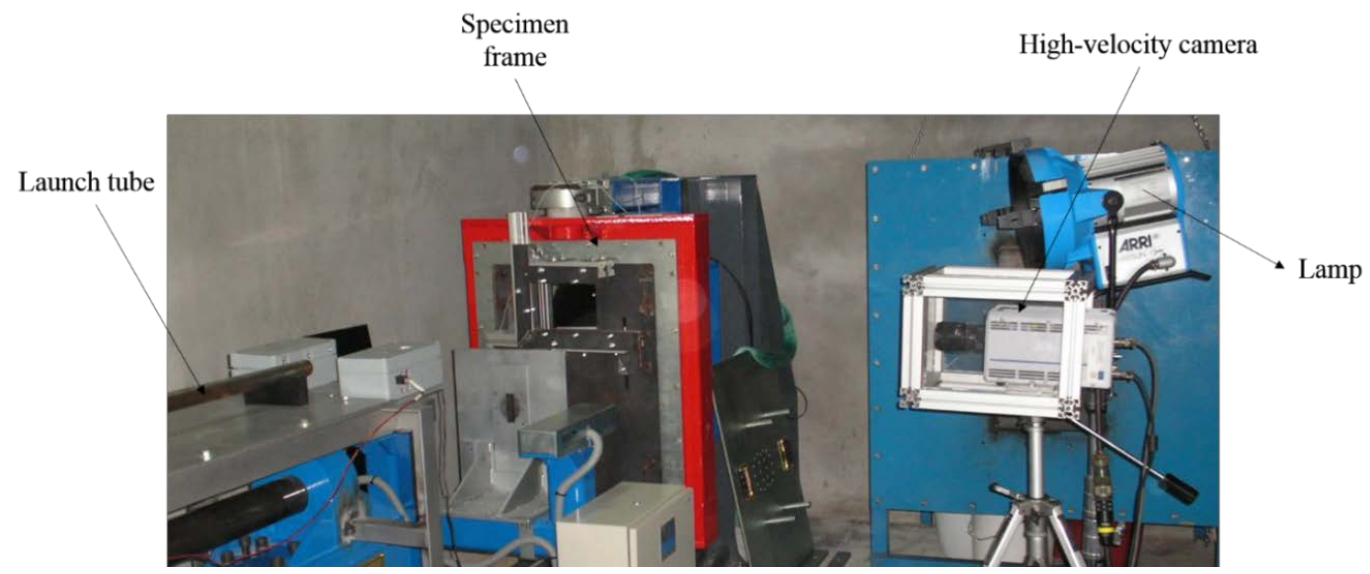

Figure 2. Photo of the high-velocity impact test setup. 
After the impact tests, non-destructive testing (NDT) was carried out on all impacted specimens, in order to evaluate the damage extension by ultrasonic inspection, specifically C-scan. For this purpose, the air-coupled scan technique was used, because it is a good alternative to the traditional ultrasonic immersion C-scan technique when the detection of small defects (matrix cracking, fibre/matrix interface debonding, etc.) is not required, as in the present study [37,38]. Therefore, a pair of transducers with $400 \mathrm{kHz}$ centre frequency, $38 \mathrm{~mm}$ focus and $25 \mathrm{~mm}$ active diameter were used in a through-transmission configuration.

Finally, residual strength was obtained by three-point bending (3PB) static tests performed with a spam of $80 \mathrm{~mm}$ in a Shimadzu AG-10 (Riverwood Drive Columbia, SC, USA) universal testing machine equipped with a $5 \mathrm{kN}$ load cell, strain rate of $5 \mathrm{~mm} / \mathrm{s}$ and at room temperature.

\section{Results and Discussion}

Figure 3 shows the absorbed energy regarding impact energy for all the specimens. The variation of the absorbed energy with impact energy is very similar for both type of plates. Below perforation, the plates absorb all the kinetic energy of the projectile, mainly by damage. When the impact energy increases above perforation, the absorbed energy decreases asymptotically.

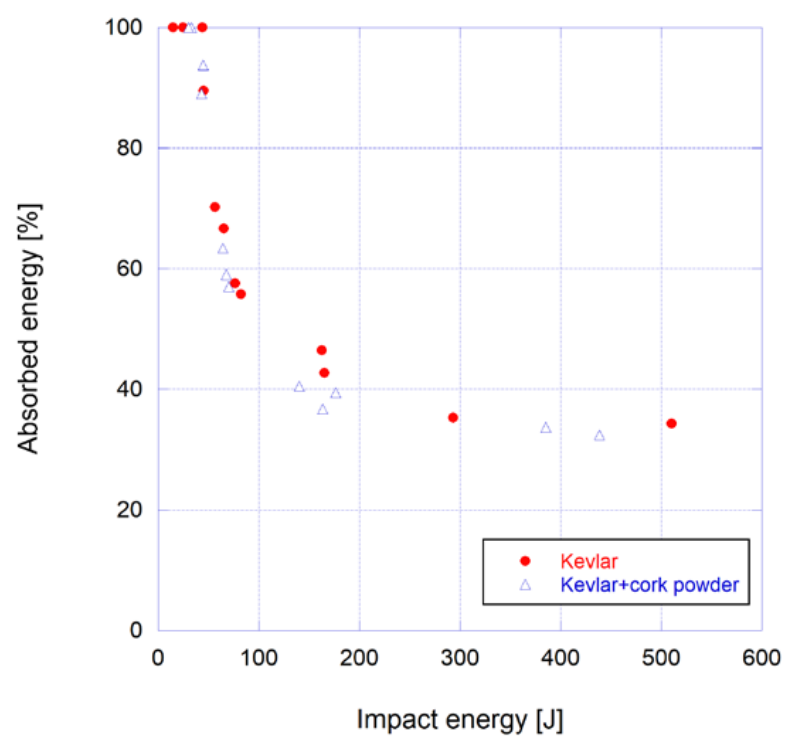

Figure 3. Impact energy vs. absorbed velocity.

It was not possible to calculate the minimum perforation velocity in a determinist manner, as an impact-velocity interval exists in which the structure may or may not be entirely perforated. In addition, the residual velocity of the projectile from the gas gun cannot be fully controlled. For this reason, a high level of scatter was found in the data obtained from the experimental tests around the minimum perforation velocity. To obtain this velocity, a least-squares method was used, by fitting Equation (1) which is similar to that proposed in the model of Recht and Ipson [39]. This method has been used successfully to predict the minimum perforation velocity in laminate and sandwich structures subjected to high velocity impacts [30,40-42].

$$
v_{r}=\left\{\begin{array}{c}
0 \text { if } 0 \leq v_{i}<v_{b l} \\
v_{r}=A \cdot\left(v_{i}^{p}-v_{b l}^{p}\right)^{\frac{1}{p}} \text { if } v_{i}>v_{b l}
\end{array}\right.
$$

where: $v_{r}$ is the residual velocity, $v_{i}$ the impact velocity, $v_{b l}$ the minimum velocity of perforation and $p$ and $A$ are fitting parameters.

Therefore, the minimum velocity of perforation is about $206.35 \pm 4.20 \mathrm{~m} / \mathrm{s}$ for Kevlar laminates with neat resin, while for that with resin filled with cork powder is around $209.71 \pm 4.63 \mathrm{~m} / \mathrm{s}$. Regardless of 
the small difference in terms of average values (1.6\%), both values are similar because they are within the experimental dispersion. In fact, cork is a hydrophobic material with a surface energy of $18 \mathrm{mN} \cdot \mathrm{m}^{-1}$, while the typical cured epoxies have surface energy of about $45 \mathrm{mN} \cdot \mathrm{m}^{-1}$ and a poor adhesion occurs for substrates with a surface energy of $30 \mathrm{mN} . \mathrm{m}^{-1}$ or lower. However, this weakness is countered by the larger external surfaces of the particles [36]. Regardless of the improvements obtained in terms of surface energy using surface treatments [43,44], Barbosa et al. [44] report that some of them destroy part of the honeycomb structure of the cork cells (erosion of cork cell walls). In this case, the damage caused to the particles can facilitate the penetration of the resin with the consequent decrease on the absorption of energy, because the damping effect of cork is lost. Therefore, while the bonds that occur when the adhesive diffuses into cell walls to build chemical bonds with the cell's chemical components are weaker, the particles' morphology promotes the physical bonds with the penetration of the epoxy resin into the open cells and consequent mechanical interlocking. In this context, the cork particles are surrounded by resin, and the closed cells that contain air inside can deform when they suffer an impact force and absorb that impact [44]. For this reason, small particles show less improvement than larger particles, because the number of open through-cut cells increases, and the resin does not allow the cell deformation. Consequently, they cannot absorb as much energy. Therefore, the response of the cork/resin composite is influenced by the number of closed cells in the particle [44]

In addition to the benefit obtained in terms of impact, it is unquestionable that the cork powder reduces the amount of resin in the composite, making it more environmentally friendly. These results are in good agreement with the open literature, where Reis et al. [34] observed, for example, that fatigue life is insensitive to the presence of cork powder into the resin. Simultaneously, these authors obtained benefits in terms of impact strength and glass transition temperature [32,33].

To understand these results, the failure mechanisms are shown in detail and Figures 4 and 5 . They show typical images obtained from visual inspection for the back side of the plates. Figure 4 shows the specimens of Kevlar and Kevlar with cork powder impacted at similar velocities, close to the perforation velocity, while the specimens of Figure 5 were impacted at higher velocities.

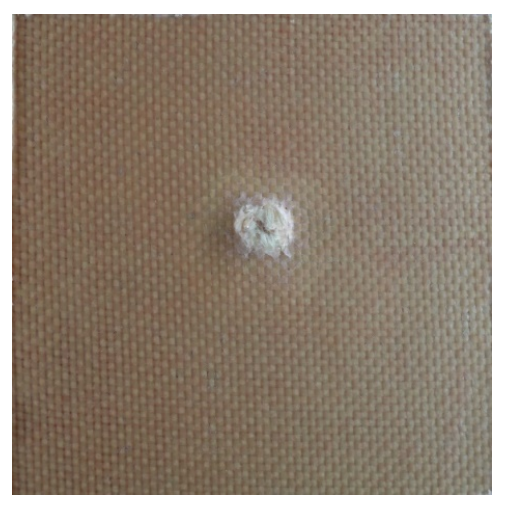

(a)

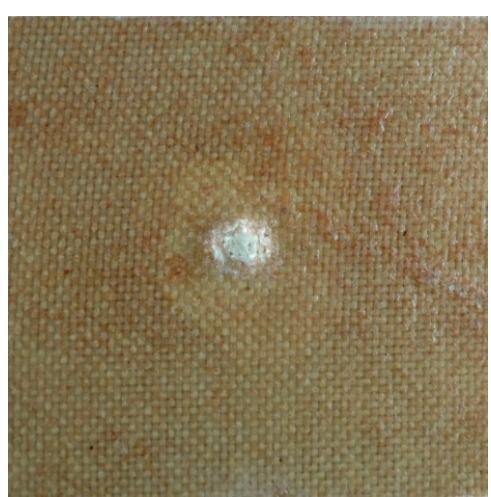

(b)

Figure 4. Damage area of the back side. (a) Specimen of Kevlar impacted at $231 \mathrm{~m} / \mathrm{s}$ and (b) specimen of Kevlar + cork powder impacted at $230 \mathrm{~m} / \mathrm{s}$.

From the visual inspections of the back sides of the plates (Figures 4 and 5), it is visible that the failure mechanisms are: fibre failure and delamination. Although matrix cracking is not possible to identify by visual inspection, this is one of the first damage mechanisms in composite laminates, and therefore, it should appear since it induces other failures modes, as delamination [45].

The images of the damaged area that were obtained by C-scan in the samples subjected to different impact velocities are shown in Figures 6 and 7. The impact velocities coincide with the impact velocities of the samples showed in Figures 4 and 5. In all specimens inspected by C-scan, it was possible to observe that the damaged areas had circular shapes, a behaviour that also appears in woven glass laminates [46]. 


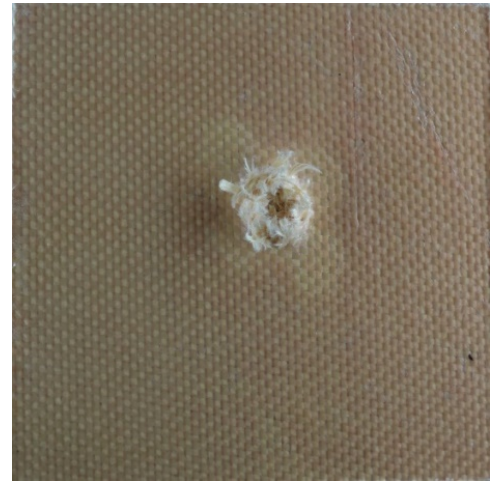

(a)

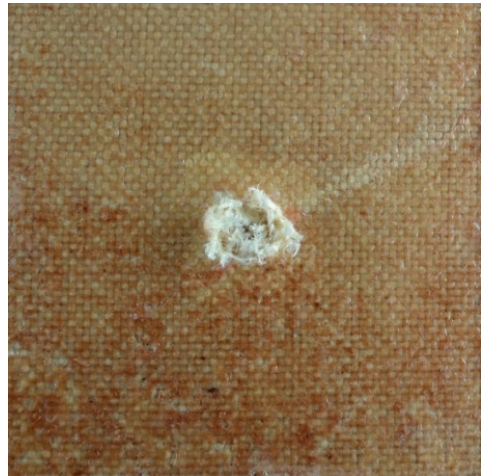

(b)

Figure 5. Image of damage area of the back side. (a) Specimen of Kevlar impact to $438 \mathrm{~m} / \mathrm{s}$ and (b) specimen of Kevlar + cork powder impacted to $439 \mathrm{~m} / \mathrm{s}$.

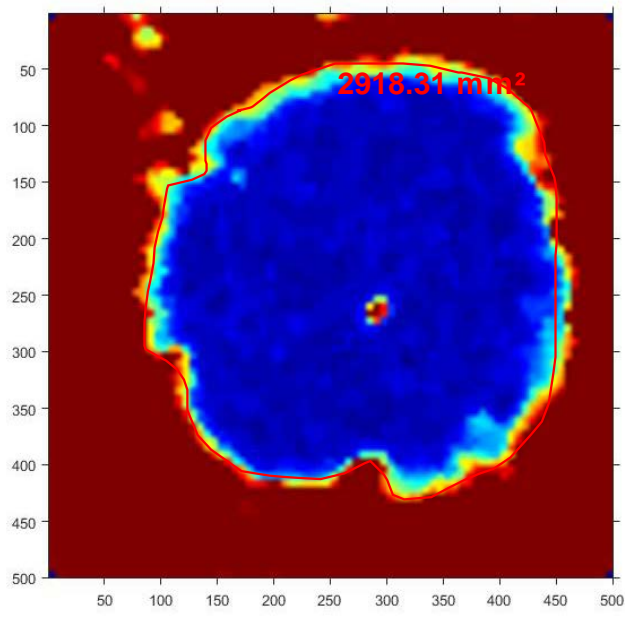

(a)

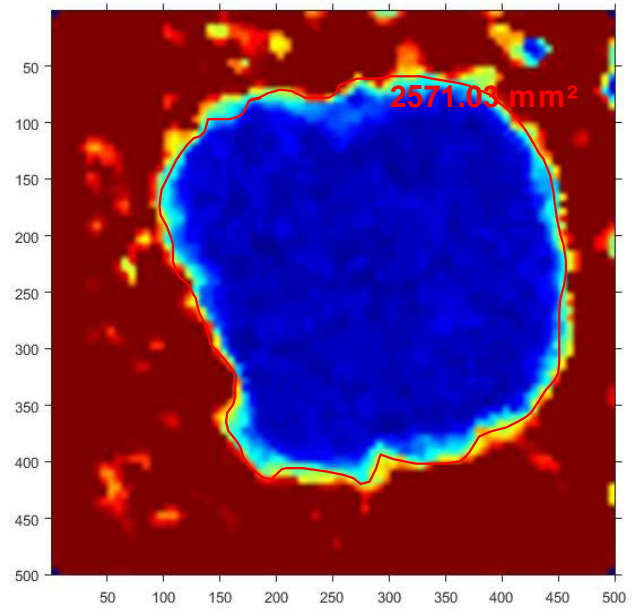

(b)

Figure 6. Images of damage areas by C-scan. (a) Specimen of Kevlar impact to $231 \mathrm{~m} / \mathrm{s}$ and (b) specimen of Kevlar + cork powder impacted to $230 \mathrm{~m} / \mathrm{s}$.

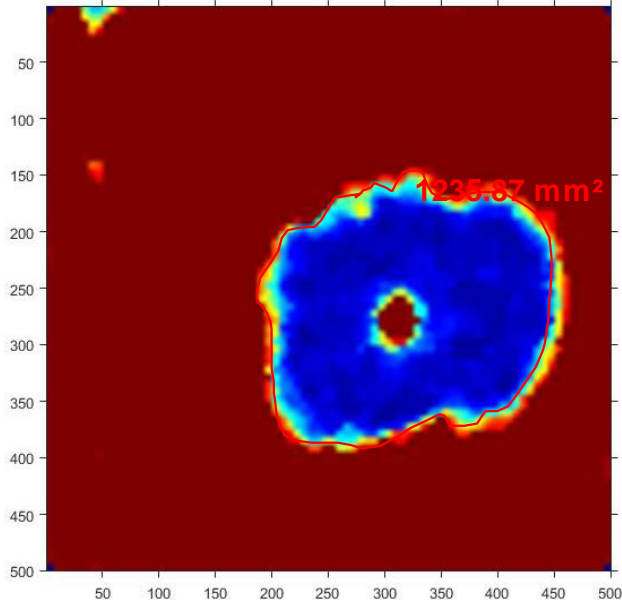

(a)

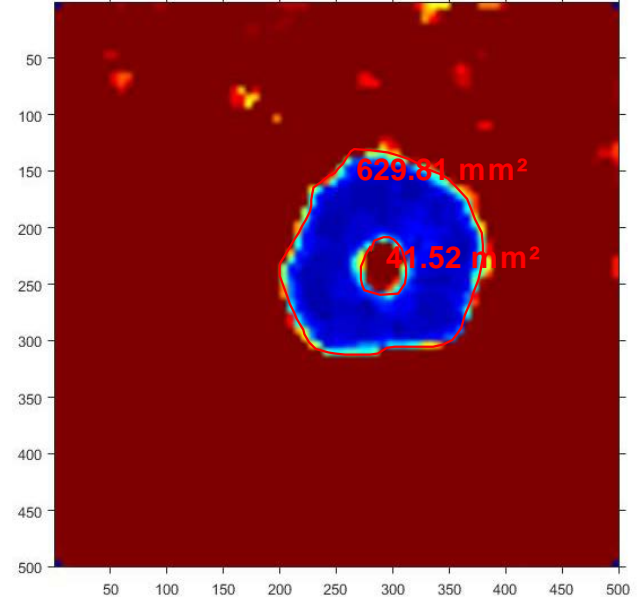

(b)

Figure 7. Images of damage areas by C-scan. (a) Specimen of Kevlar impact to $438 \mathrm{~m} / \mathrm{s}$ and (b) specimen of Kevlar + cork powder impacted to 439 m/s. 
The specimens impacted at higher velocities, around $300 \mathrm{~m} / \mathrm{s}$, showed fibre breakage close to the impact point, as reported in Figures 5 and 7. Simultaneously, the C-scan images clearly show that the damage caused by the bullets not only causes local damage (macro damage), but also affects the vicinity of the damaged areas clearly seen in different colours (micro damage), which agrees with the studies developed by Dhakal et al. [47]. Moreover, the extension of damage is more located around the impact point at higher velocities, as can be seen in Figure 7. In this context, the extension of damage area determined by the C-scan inspection is larger than the damage established by the visual inspection on both sides of the laminate (front and back face).Therefore, in addition to macro-damage, it is evident that the impact also induces internal micro-damage that is not visible to the naked eye, but should be considered when quantifying the damage size [47].

Figure 8 shows the extension of damage area for all specimens measured by C-scan. In all structures, the larger damaged area was found for velocities around the minimum perforation velocity. For velocities below the minimum perforation velocity, the damaged area increases with velocity, while for velocities greater than the perforation velocity, the damaged area decreases with increasing velocity.

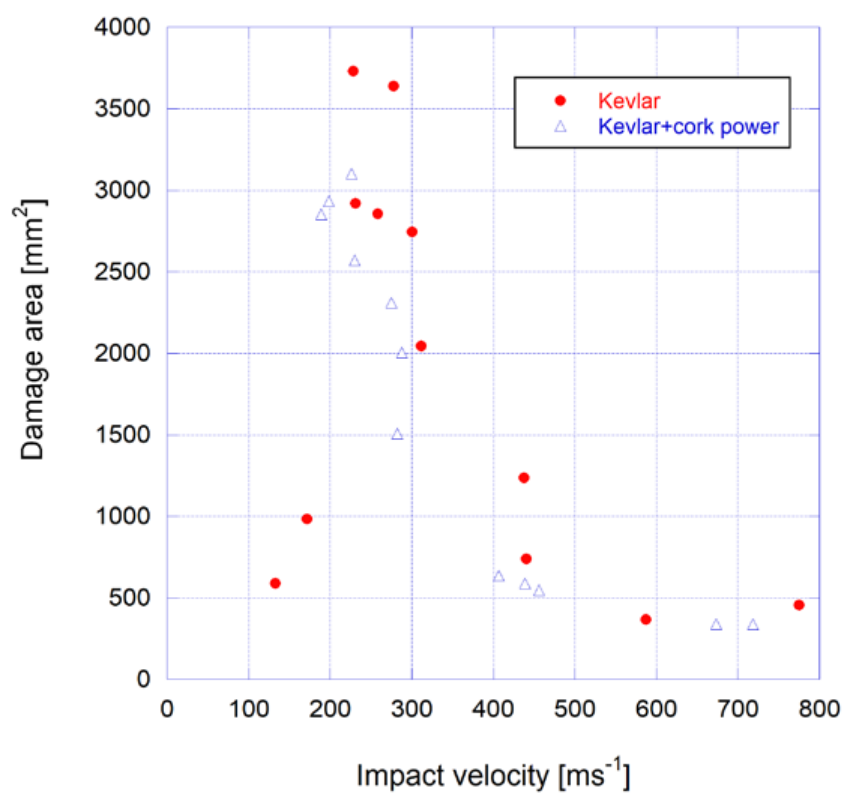

Figure 8. Extension of damage area measured by C-scan.

This behaviour was observed by Buitrago et al. [48] for glass woven laminates, and it is produced by the bending of the plate due to the transverse wave travel, which leads to delamination. Since the contact time is maximal at the perforation velocity, the distance travelled by the transverse wave is also maximal, and thus the delaminated area is too [46,49]. On the other hand, when the damaged areas are compared between laminates with neat resin and resin filled by cork powder, in all conditions there is a clear tendency for the last ones to have smaller damaged areas. For example, comparing the damaged areas shown in Figures 6 and 7, it is possible to observe that for impact velocities around $230 \mathrm{~m} / \mathrm{s}$, they are around $11.9 \%$ lower for laminates with cork powder. However, this value was around $45.7 \%$ lower for impact velocities of $438 \mathrm{~m} / \mathrm{s}$. Nevertheless, for the highest impact velocities, the damaged areas tend to be similar. This behaviour allows one to affirm that there are changes in the energy absorption mechanisms, although there is not much change in the ballistic behaviour (Figure 3). In fact, cork has a high capacity to absorb energy, and as reported above, the response of the cork/resin composite is influenced by the number of closed cells in the cork particles. Sanchez-Saez et al. [29] observed a great capacity to absorb energy even after several consecutive impacts. In addition, Sarasini et al. [30] observed in their studies that the absorption of energy in high deformations can be quite considerable without signs of breaking of the cell walls, because an almost complete recovery of their original shape and size occurs. 
Finally, Figure 9 shows the residual bending strength, where $\sigma$ is the average bending stress for each velocity and $\sigma_{0}$ is the average bending stress obtained from the 3PB static tests for each laminate.

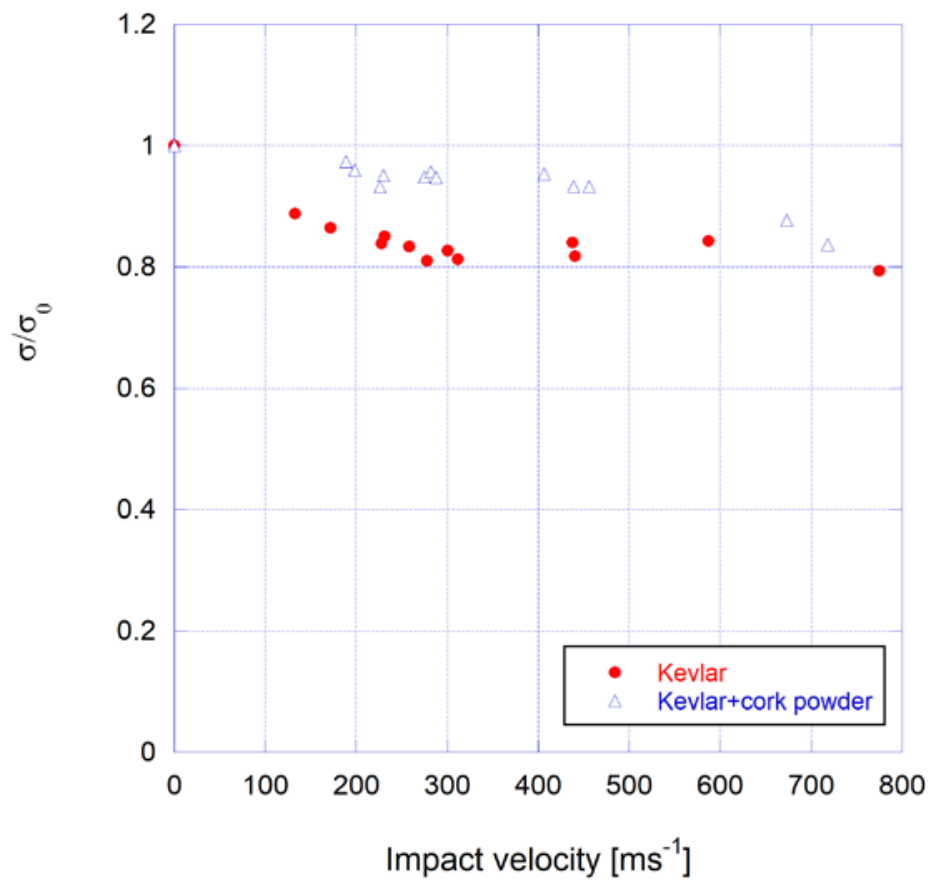

Figure 9. Impact velocity vs. ratio of bending stress.

Regardless of the lower static bending strength (around 13.7\% less when $3 \mathrm{wt} . \%$ of cork powder was added to the resin), which agrees with the studies developed by Reis et al. [34], it is possible to observe that laminates incorporating cork powder are less sensitive to impact velocity than the samples with neat resin. This is explained by the lower damaged areas that were previously reported for laminates with cork powder, due to the high capacity to absorb energy from the fillers. In addition to that, Barbosa et al. [44] observed that cork particles act like obstacles to crack propagation. This evidence also explains the better bending performance obtained for laminates with cork powder. On the other hand, and independently of the laminate, it is also evident that the maximum bending strength decreases for velocities below the minimum perforation velocity, and that there is a tendency for it to remain constant for velocities greater than the perforation velocity. However, the observed decrease was more expressive for laminates with neat resin due to the greater damage areas observed (as reported above).

\section{Conclusions}

The high-velocity impact and post impact behaviours of Kevlar/epoxy composites, in which the epoxy matrix is filled with cork powder, have been studied.

In terms of average values, the minimum velocity of perforation was $1.6 \%$ higher for laminates with cork powder, but this difference can be neglected in view of the dispersion obtained in the experimental tests. The damage areas increase for velocities below the minimum perforation velocity, but the opposite trend occurs for velocities greater than the perforation velocity. However, regardless the impact velocity, the C-scan images reveal that lesser damage areas are obtained for laminates with cork powder, especially for impact velocities close to perforation velocity. Consequently, considering the residual bending strength, these laminates are less sensitive to impact velocity than the samples with neat resin. In addition to these benefits, cork powder reduces the amount of resin in the composite, making it more environmentally friendly. Finally, in addition to these benefits, laminates with cork powder are more environmentally friendly due to their lower percentages by weight of resin. 
Author Contributions: A.M.A. performed the NDT tests, analysed the results and helped to write the manuscript; P.N.B.R. produced the laminates and helped to write the manuscript. I.I., S.S.-S., S.K.G.-C. and E.B. carried out the high-velocity impact tests; contributed in the acquisition, analysis and interpretation of data; and helped to write the manuscript. All authors have read and agreed to the published version of the manuscript.

Funding: The authors are indebted to the Ministerio de Economía y Competitividad de España for the funds received for this work within the framework of the project DPI2017-86324-R. This research is sponsored by FEDER funds through the program COMPETE-Programa Operacional Factores de Competitividade-and by national funds through FCT-Fundação para a Ciência e a Tecnologia, under the project UIDB/00285/2020.

Conflicts of Interest: Authors declare no conflict of interest.

\section{References}

1. Zanjani, N.A.; Wang, W.; Kalyanasundaram, S. The effect of fiber orientation on the formability and failure behavior of a woven self-reinforced composite. J. Manuf. Sci. Eng. 2015, 137, 051012. [CrossRef]

2. Gholampour, T.; Ozbakkaloglu, A. A review of natural fiber composites: Properties, modification and processing techniques, characterization, applications. J. Mater. Sci. 2020, 55, 829-892. [CrossRef]

3. Vijayana, R.; Krishnamoorthy, A. Review on natural fiber reinforced composites. Mater. Today Proc. 2019, 16, 897-906. [CrossRef]

4. Elanchezhian, C.; Ramnath, B.V.; Ramakrishnan, G.; Rajendrakumar, M.; Naveenkumar, V.; Saravanakumar, M.K. Review on mechanical properties of natural fiber composites. Mater. Today Proc. 2018, 5, 1785-1790. [CrossRef]

5. Mohammed, L.; Ansari, M.N.M.; Pua, G.; Jawaid, M.; Islam, M.S. A Review on natural fiber reinforced polymer composite and its applications. Int. J. Polym. Sci. 2015, 2015, 243947. [CrossRef]

6. Peças, P.; Carvalho, H.; Hafiz Salman, H.; Leite, M. Natural fibre composites and their applications: A review. J. Compos. Sci. 2018, 2, 66. [CrossRef]

7. Chauhan, V.; Kärki, T.; Varis, J. Review of natural fiber-reinforced engineering plastic composites, their applications in the transportation sector and processing techniques. J. Thermoplast. Compos. Mater. 2019. [CrossRef]

8. Thomason, J.L.; Rudeiros-Fernández, J.L. A Review of the impact performance of natural fibre thermoplastic composites. Front. Mater. 2018. [CrossRef]

9. Pickering, K.L.; Efendy, M.G.A.; Le, T.M. A review of recent developments in natural fibre composites and their mechanical performance. Compos. Part A Appl. Sci. Manuf. 2016, 83, 98-112. [CrossRef]

10. Nuthong, W.; Uawongsuwan, P.; Pivsa-Art, W.; Hamada, H. Impact property of flexible epoxy treated natural fiber reinforced PLA composites. Energy Procedia 2013, 34, 839-847. [CrossRef]

11. Saheb, D.N.; Jog, J.P. Natural fiber polymer composites: A review. Adv. Polym. Technol. 1999, 18, 351-363. [CrossRef]

12. Folkes, M.J. Short Fiber Reinforced Thermoplastic Composites; John Wiley and Sons: New York, NY, USA, 1982.

13. Bledzki, A.K.; Gassan, J. Natural fiber reinforced plastics. In Handbook of Engineering Polymeric Materials; Marcel Dekker, Inc.: New York, NY, USA, 1997; pp. 787-810.

14. Joseph, P.V.; Joseph, K.; Thomas, S. Effect of processing variables on the mechanical properties of sisal-fiber-reinforced polypropylene composites. Compos. Sci. Technol. 1999, 59, 1625-1640. [CrossRef]

15. Jayaraman, K. Manufacturing sisal-polypropylene composites with minimum fibre degradation. Compos. Sci. Technol. 2003, 63, 367-374. [CrossRef]

16. Reis, P.N.B.; Ferreira, J.A.M.; Antunes, F.V.; Costa, J.D.M. Flexural behaviour of hybrid laminated composites. Compos. Part A Appl. Sci. Manuf. 2007, 38, 1612-1620. [CrossRef]

17. Rosa, M.E.; Fortes, M.A. Deformation and fracture of cork in tension. J. Mater. Sci. 1991, 26, 341-348. [CrossRef]

18. Rosa, M.E.; Fortes, M.A. Water-absorption by cork. Wood Fiber Sci. 1993, 25, 339-348.

19. Vaz, M.F.; Rosa, M.E. Friction Properties of cork. J. Mater. Sci. 1998, 33, 2087-2093. [CrossRef]

20. Mano, J.F. The viscoelastic properties of cork. J. Mater. Sci. 2002, 37, 257-263. [CrossRef]

21. Mislata, A.M.; Puxeu, M.; Ferrer-Gallego, R. Aromatic potential and bioactivity of cork stoppers and cork by-products. Foods 2020, 9, 133. [CrossRef]

22. Sepúlveda, F.J.; Arranz, J.I.; Miranda, M.T.; Montero, I.; Rojas, C.V. Drying and pelletizing analysis of waste from cork granulated industry. Energies 2018, 11, 109. [CrossRef] 
23. Gil, L. Cork powder waste: An overview. Biomass Bioenergy 1997, 13, 59-61. [CrossRef]

24. Pintor, A.M.A.; Ferreira, C.I.A.; Pereira, J.C.; Correia, P.; Silva, S.P.; Vilar, V.J.P.; Botelho, C.M.S.; Boaventura, R.A.R. Use of cork powder and granules for the adsorption of pollutants: A review. Water Res. 2012, 46, 3152-3166. [CrossRef]

25. Pintor, A.M.A.; Vieira, B.R.C.; Boaventura, R.A.R.; Botelho, C.M.S. Removal of antimony from water by iron-coated cork granulates. Sep. Purif. Technol. 2020, 233, 116020. [CrossRef]

26. Olivella, M.A.; Jové, P.; Oliveras, A. The use of cork waste as a biosorbent for persistent organic pollutants-study of adsorption/desorption of polycyclic aromatic hydrocarbons. J. Environ. Sci. Health. Part A 2011, 46, 824-832. [CrossRef]

27. Gil, L. Cork composites: A review. Materials 2009, 2, 776-789. [CrossRef]

28. Fernandes, E.M.; Correlo, V.M.; Chagas, J.A.M.; Mano, J.F.; Reis, R.L. Properties of new cork-polymer composites: Advantages and drawbacks as compared with commercially available fibreboard materials. Compos. Struct. 2011, 93, 3120-3129. [CrossRef]

29. Sánchez-Sáez, S.; Barbero, E.; García-Castillo, S.K.; Ivañez, I.; Cirne, J. Experimental response of agglomerated cork under multi-impact loads. Mater. Lett. 2015, 160, 327-330. [CrossRef]

30. Sarasini, F.; Tirillò, J.; Lampani, L.; Barbero, E.; Sanchez-Saez, S.; Valente, T. Impact behavior of sandwich structures made of flax/epoxy face sheets and agglomerated cork. J. Nat. Fibers. 2020, 17, 168-188. [CrossRef]

31. Ivañez, I.; Sánchez-Saez, S.; Garcia-Castillo, S.K.; Barbero, E.; Amaro, A.M.; Reis, P.N. Impact response of repaired sandwich structures. Polym Compos. 2020. [CrossRef]

32. Reis, P.N.B.; Ferreira, J.A.M.; Silva, P.A.A. Mechanical behaviour of composites filled by agro-waste materials. Fiber. Polym. 2011, 12, 240-246. [CrossRef]

33. Reis, P.N.B.; Ferreira, J.A.M.; Santos, P.; Richardson, M.O.W.; Santos, J.B. Impact response of Kevlar composites with filled epoxy matrix. Compos. Struct. 2012, 94, 3520-3528. [CrossRef]

34. Reis, P.N.B.; Ferreira, J.A.M.; Costa, J.D.M.; Santos, M.J. Fatigue performance of Kevlar/epoxy composites with filled matrix by cork powder. Fiber. Polym. 2012, 13, 1292-1299. [CrossRef]

35. Reis, P.N.B.; Silva, M.P.; Santos, P.; Parente, J.M.; Bezazi, A. Viscoelastic behaviour of Composites with Epoxy Matrix Filled by Cork Powder. Compos. Struct. 2020, 234, 111669. [CrossRef]

36. Pereira, H. The rationale behind cork properties: A review of structure and chemistry. BioResources 2015, 10, 1-23. [CrossRef]

37. Amaro, A.M.; Reis, P.N.B.; Santos, J.B.; Santos, M.J.; Neto, M.A. Effect of the electric current on the impact fatigue strength of CFRP composites. Compos. Struct. 2017, 182, 191-198. [CrossRef]

38. Santos, M.J.; Santos, J.B.; Reis, P.N.B.; Amaro, A.M. Ultrasonic C-scan techniques for damage evaluation of carbon fiber reinforced polymers submitted to low energy impacts. Proc. Mtgs. Acoust. 2019, 38, 030002.

39. Recht, R.F.; Ipson, T.W. Ballistic perforation dynamics. J. Appl. Mech. T ASME 1963, 30, 384-390. [CrossRef]

40. García-Castillo, S.K.; Buitrago, B.L.; Barbero, E. Behavior of sandwich structures and spaced plates subjected to high-velocity impacts. Polym. Compos. 2011, 32, 290-296. [CrossRef]

41. Sánchez-Sáez, S.; Barbero, E.; Cirne, J. Experimental study of agglomerated-cork-cored structures subjected to ballistic impacts. Mater. Lett. 2011, 65, 2152-2154. [CrossRef]

42. Ivañez, I.; Sánchez-Saez, S.; Garcia-Castillo, S.K.; Barbero, E.; Amaro, A.; Reis, P.N.B. High-velocity impact behaviour of damaged sandwich plates with agglomerated cork core. Compos. Struct. 2020, 112520. [CrossRef]

43. Abenojar, J.; Barbosa, A.Q.; Ballesteros, Y.; del Real, J.C.; da Silva, L.F.M.; Martinez, M.A. Effect of surface treatments on natural cork: Surface energy, adhesion, and acoustic insulation. Wood Sci. Technol. 2014, 48, 207-224. [CrossRef]

44. Barbosa, A.Q.; da Silva, L.F.M.; Öchsner, A.; Abenojar, J.; del Real, J.C. Influence of the size and amount of cork particles on the impact toughness of a structural adhesive. J. Adhes. 2012, 88, 452-470. [CrossRef]

45. Moure, M.M.; Otero, F.; García-Castillo, S.K.; Sánchez-Sáez, S.; Barbero, E.; Barbero, E.J. Damage evolution in open-hole laminated composite plates subjected to in-plane loads. Compos. Struct. 2015, 133, 1048-1057. [CrossRef]

46. Gil-Alba, R.; Alonso, L.; Navarro, C.; García-Castillo, S.K. Morphological study of damage evolution in woven-laminates subjected to high-velocity impact. Mech. Adv. Mater. Struc. 2019, 26, 2023-2029. [CrossRef]

47. Dhakal, H.N.; Zhang, Z.Y.; Bennett, N.; Reis, P.N.B. Low-velocity impact response of non-woven hemp fibre reinforced unsaturated polyester composites: Influence of impactor geometry and impact velocity. Compos. Struct. 2012, 94, 2756-2763. [CrossRef] 
48. Buitrago, B.L.; García-Castillo, S.K.; Barbero, E. Experimental analysis of perforation of glass/polyester structures subjected to high-velocity impact. Mater. Lett. 2010, 64, 1052-1054. [CrossRef]

49. García-Castillo, S.K.; Sánchez-Sáez, S.; Barbero, E. Nondimensional analysis of ballistic impact on thin woven laminate plates. Int. J. Impact Eng. 2012, 39, 8-15. [CrossRef]

(C) 2020 by the authors. Licensee MDPI, Basel, Switzerland. This article is an open access article distributed under the terms and conditions of the Creative Commons Attribution (CC BY) license (http://creativecommons.org/licenses/by/4.0/). 